\title{
Double blinded study on comparison of phosphorylated insulin like growth factor binding protein 1 test and fetal fibronectin test for prediction of preterm delivery
}

\author{
Seema Singhal ${ }^{1 *}$, Nivedita $\operatorname{Sarda}^{2}$, Niharika Dhiman ${ }^{3}$, Kusum Dogra $^{2}$
}

\author{
${ }^{1}$ Department of Obstetrics and Gynecology, All India Institute of Medical sciences, New Delhi, India \\ ${ }^{2}$ Department of Obstetrics and Gynecology, VMMC and Safdarjang Hospital, New Delhi, India \\ ${ }^{3}$ Department of Obstetrics and Gynecology, Maulana Azad Medical College and LNJP Hospital, New Delhi, India
}

Received: 31 December 2016

Accepted: 23 February 2017

\section{*Correspondence:}

Dr. Seema Singhal,

E-mail: drseemasinghal@gmail.com

Copyright: (C) the author(s), publisher and licensee Medip Academy. This is an open-access article distributed under the terms of the Creative Commons Attribution Non-Commercial License, which permits unrestricted non-commercial use, distribution, and reproduction in any medium, provided the original work is properly cited.

\begin{abstract}
Background: Recently new markers like fetal fibronectin (FFN) and phosphorylated Insulin like growth factor binding protein 1 (phIGFBP-1) have been found useful in diagnosis of pre-term labor. Fetal fibronectin (FFN) and phosphorylated Insulin like growth factor binding protein 1 (phIGFBP-1) were compared to predict the risk of pre- term delivery.

Methods: Cervicovaginal samples of 50 symptomatic and 50 asymptomatic pregnant women were tested. Statistical analysis was done using chi square test, fisher's exact test for qualitative data and for quantitative data unpaired student t test and Mann Whitney test were used.

Results: For Symptomatic group phosphorylated Insulin like growth factor binding protein 1 (phIGFBP-1) and fetal fibronectin (FFN) had $100 \%$ sensitivity and $100 \%$ NPV for predicting delivery within 48 hours, 7 days and 14 days. Specificity and PPV of FFN was higher than phIGFBP-1 to predict delivery (Specificity: within 48 hours $63.2 \%$ vs $52.6 \%$ within 7 days $72.7 \%$ vs $60.6 \%$, within 14 days $75 \%$ vs $62.5 \%, \leq 37$ weeks $76 \%$ vs $56 \%$; PPV: within 48 hours $46.2 \%$ vs $40 \%$, within 7 days $65.4 \%$ vs $56.7 \%$, within 14 days was $69.2 \%$ vs $60 \%$ and $\leq 37$ weeks $76.9 \%$ vs $63 \%$ ).

Conclusions: Rapid bed side dip stick tests for detecting FFN and ph IGFBP-1 in cervicovaginal secretions are useful clinical adjuncts in ruling out delivery within 14 days of test in symptomatic patients, thus avoiding unnecessary hospital stay and medical interventions. However, FFN has slightly higher NPV in predicting risk of pre term delivery.
\end{abstract}

Keywords: Actim partus test, Cervical length, Fetal fibronectin test, Phosphorylated insulin like growth factor binding protein 1 test, Preterm delivery, Quik chek test

\section{INTRODUCTION}

Preterm birth is the leading cause of perinatal morbidity and mortality, however, only $20 \%$ of women presenting with preterm labour will actually deliver. ${ }^{1}$ Diagnosis of preterm labor is important for in utero transfer to higher centers so that appropriate neonatal care can be provided. Several clinical and biochemical markers either alone or in combination have been used to predict the risk of pre-term delivery but with limited clinical utility. ${ }^{2}$ Recently new markers like fetal fibronectin (FFN) and phosphorylated Insulin like growth factor binding protein 1 (phIGFBP-1) have been found useful in diagnosis of pre-term labor. ${ }^{2}$

Fetal fibronectin is found in amniotic fluid, placenta, and decidua and its presence in cervicovaginal fluid after 20 weeks is a marker for pre-term labor. An enzyme linked immunosorbant assay containing FDC-6 monoclonal 
antibody has been developed that can be used bed side. ${ }^{2}$ Human decidual cells also secrete phosphorylated isoforms of phIGFBP-1 including the highly phosphorylated one. Actim partus test (Medix biochemical) is a rapid bed side test, and was developed to detect the presence of phIGFBP-1 in cervical secretions. ${ }^{3}$

The phIGFBP-1 and FFN bedside dipstick tests hold the promise in identifying those symptomatic women who are least likely to deliver prematurely. ${ }^{4,5}$ Studies have been done to predict accuracy of phIGFBP-1 and FFN. , $^{6,7}$ There have been attempts to combine cervical length with either FFN or phIGFBP-1 to improve the accuracy, however with inconsistent results. ${ }^{89}$ Certain studies have found FFN better than phIGFBP-1 or vice versa. ${ }^{4,8}$ Not enough studies have been published to compare the two tests. In present study we evaluated two rapid bed side tests (FFN and ph IGFBP-1) for prediction of pre-term labor. The aim of this study was to compare the effectiveness of phIGFBP-1 and fetal fibronectin for prediction of preterm delivery.

\section{METHODS}

Present study was conducted at Vardhman Mahavir Medical College and associated safdarjang Hospital New Delhi a tertiary care teaching hospital. Fifty pregnant women between 20-35 weeks of gestation presenting with symptoms of preterm labor viz pelvic pressure, low abdominal cramps and uterine contractions were recruited as symptomatic group. The patients who presented with premature rupture of membranes, cervical dilatation $>3$ $\mathrm{cm}$, bleeding per vaginum, indications requiring expediation of delivery like IUGR, fetal anomalies, severe preeclampsia were excluded. Another 50 pregnant women with prior history of pre-term birth or second trimester miscarriage but without any symptoms of pre-term labor were taken as asymptomatic group.

Informed consent was taken from all the participants. After taking detailed history and examination cervicovaginal samples were collected and analyzed for presence of FFN and PhIGFBP-1 using the Quik Check FFN rapid test and Actim $^{\mathrm{TM}}$ Partus test respectively for all the participants. Cervical length was measured by transvaginal sonography. Obstetricians and patients were blinded to the results. Tocolytic and steroid therapy were administered to symptomatic patients. The women in asymptomatic group did not receive any intervention. All the patients were followed till delivery. The sensitivity, specificity, positive predictive value (PPV) and negative predictive value (NPV) for both the tests in prediction of delivery within 48 hours, 7 days and 14 days and pre term delivery was calculated. Qualitative data was analyzed by using unpaired student $\mathrm{t}$ test and Mann Whitney test. Multiple logistic regressions were performed to assess the independent contribution of different variables in prediction of pre-term delivery. To find the measure of agreement between phIGFBP-1 and FFN test kappa analysis was done. SPSS statistical software version 12.0 was used for data analysis.

\section{RESULTS}

Demographical variables were studied for both symptomatic and symptomatic group (Table 1).

Table1: Demographic variables in symptomatic and asymptomatic group.

\begin{tabular}{|lll|}
\hline $\begin{array}{l}\text { Variable (Mean } \\
\pm \text { SD) }\end{array}$ & $\begin{array}{l}\text { Symptomatic } \\
\text { group }\end{array}$ & $\begin{array}{l}\text { Asymptomatic } \\
\text { group }\end{array}$ \\
\hline Maternal age (yrs) & $23.38 \pm 3.7$ & $24.12 \pm 2.94$ \\
\hline $\begin{array}{l}\text { Gestational age } \\
\text { (weeks) }\end{array}$ & $29.9 \pm 3.6$ & $29.44 \pm 2.92$ \\
\hline BMI $\left(\mathrm{kg} / \mathrm{m}^{2}\right)$ & $25.6 \pm 7.4$ & $25.39 \pm 6.34$ \\
\hline $\begin{array}{l}\text { Cervical length } \\
(\mathrm{mm})\end{array}$ & $36.554 \pm 4.43$ & $37.230 \pm 4.9$ \\
\hline
\end{tabular}

\section{Symptomatic group}

In symptomatic group 26 patients were tested positive for FFN. Out of these 26 patients $18(69.2 \%)$ delivered within 14 days and eight $(30.7 \%)$ delivered after 14 days. All 24 women who were FFN negative delivered after 14 days of test. Out of $18 \mathrm{FFN}$ positive patients who delivered within 14 days 12 had delivery within 48 hours. 17/18 had delivery within 7 days and 18/18 within 14 days of test. Out of 26 FFN positive patients $20(76.9 \%)$ had preterm and six (23\%) had term (>37 weeks) births. Among the 24 negatively tested women five $(20.8 \%)$ had preterm births and $19(79.2 \%)$ delivered at term. Thirty women were tested positive for phIGFBP-1. Out of these 30 patients, 18 $(60 \%)$ delivered within 14 days of the test and $12(40 \%)$ delivered after 14 days. All 20 women who were negative for phIGFBP-1 test delivered after 14 days. Twelve patients out of 30 positives delivered within 48 hours, $17 / 30$ within 7 days, $18 / 30$ within 14 days.Out of 30 positive phIGFBP-1 women $19(63.3 \%)$ had preterm and $11(36.7 \%)$ had term (>37 weeks) delivery. Among the 20 negatively tested women $\operatorname{six}(30 \%)$ had preterm births and $14(70 \%)$ delivered at term. Sensitivity, specificity, PPV, NPV of FFN and ph IGFBP-1 test in predicting delivery within 48 hours, 7 days, 14 days and $\leq 37$ weeks was calculated (Table 2).

Mean cervical length in symptomatic group was $36.554 \pm 4.43 \mathrm{~mm}$. Thirty four $(68 \%)$ patients had cervical length $>35 \mathrm{~mm}$. Ten patients $(20 \%)$ had cervical length $26-$ $35 \mathrm{~mm}$. Six women had cervical length $\leq 25 \mathrm{~mm}$ and five $(83.3 \%)$ of them delivered within 14 days only one (16.6\%) patient delivered after 14 days. Out of 44 women with cervical length $>25 \mathrm{~mm} 12(27.2 \%)$ delivered within 14 days and $32(72.7 \%)$ delivered after 14 days. Out of six women with cervical length $\leq 25 \mathrm{~mm}$ five $(83.3 \%)$ delivered before 37 weeks and one (16.6\%) delivered after 37 weeks. Rest 44 women who had cervical lengths $>25$ $\mathrm{mm}, 20(45.4 \%)$ of them delivered pre term and 24 $(54.5 \%)$ delivered at term. Sensitivity, specificity, PPV, NPV of cervical length in predicting pre term delivery ( $\leq 37$ weeks) was $20 \%, 96 \%, 83.3 \%$ and $54.5 \%$ 
respectively. The likelihood ratio of cervical length for predicting delivery $\leq 37$ weeks was 3.275 .

Table 2: Comparison of predictive accuracy of Ph IGFBP-1 and FFN in symptomatic group.

\begin{tabular}{|c|c|c|c|c|c|c|}
\hline \multirow{5}{*}{$\begin{array}{l}\text { Delivery } \\
\leq 48 \text { hours }\end{array}$} & & Sensitivity & Specificity & PPV $^{\mu}$ & $\mathrm{NPV}^{£}$ & $\mathbf{L R}^{\S}$ \\
\hline & phIGFBP-1 & $100 \%(12 / 12)$ & $52.6 \%(20 / 38)$ & $40 \%(12 / 30)$ & $100 \%(20 / 20)$ & \multirow{2}{*}{14.72} \\
\hline & $95 \% \mathrm{CI}$ & $75.75-100$ & $37.26-67.52$ & $24.59-57.68$ & $83.89-100$ & \\
\hline & FFN & $100 \%(12 / 12)$ & $63.2 \%(24 / 38)$ & $46.2 \%(12 / 26)$ & $100 \%(24 / 24)$ & \multirow{2}{*}{19.218} \\
\hline & $95 \% \mathrm{CI}$ & $75.75-100$ & $47.28-76.62$ & $28.76-64.54$ & $86.2-100$ & \\
\hline \multirow{4}{*}{$\begin{array}{l}\text { Delivery } \\
\leq 7 \text { days }\end{array}$} & phIGFBP-1 & $100 \%(17 / 17)$ & $60.6 \%(20 / 33)$ & $56.7 \%(17 / 30)$ & $100 \%(20 / 20)$ & \multirow{2}{*}{23.05} \\
\hline & $95 \% \mathrm{CI}$ & $81.57-100$ & $43.88-75.32$ & $39.2-72.62$ & $83.89-100$ & \\
\hline & FFN & $100 \%(17 / 17)$ & $72.7 \%(24 / 33)$ & $65.4 \%(17 / 26)$ & $100 \%(24 / 24)$ & \multirow{2}{*}{30.56} \\
\hline & $95 \% \mathrm{CI}$ & $81.57-100$ & $55.78-84.93$ & $46.22-80.59$ & $86.2-100$ & \\
\hline \multirow{4}{*}{$\begin{array}{l}\text { Delivery } \\
\leq 14 \text { days }\end{array}$} & phIGFBP-1 & $100 \%(18 / 18)$ & $62.5 \%(20 / 32)$ & $60 \%(18 / 30)$ & $100 \%(20 / 20)$ & \multirow{2}{*}{24.96} \\
\hline & $95 \% \mathrm{CI}$ & $82.4-100$ & $45.27-77.07$ & $42.32-75.41$ & $83.89-100$ & \\
\hline & FFN & $100 \%(18 / 18)$ & $75 \%(24 / 32)$ & $69.2 \%(18 / 26)$ & $100 \%(24 / 24)$ & \multirow{2}{*}{33.242} \\
\hline & $95 \% \mathrm{CI}$ & $82.41-100$ & $57.89-86.75$ & $50.01-83.5$ & $86.2-100$ & \\
\hline \multirow{4}{*}{$\begin{array}{l}\text { Delivery } \\
\leq 37 \text { weeks }\end{array}$} & phIGFBP-1 & $76 \%(19 / 25)$ & $56 \%(14 / 25)$ & $63 \%(19 / 30)$ & $70 \%(14 / 20)$ & \multirow{2}{*}{5.451} \\
\hline & $95 \% \mathrm{CI}$ & $56.57-88.5$ & $37.07-73.33$ & $45.51-78.13$ & $48.1-85.45$ & \\
\hline & FFN & $80 \%(20 / 25)$ & $76 \%(19 / 25)$ & $76.9 \%(20 / 26)$ & $79.2 \%(19 / 24)$ & \multirow{2}{*}{16.661} \\
\hline & $95 \%$ CI & $60.87-91.14$ & $56.57-88.5$ & $57.95-88.97$ & $59.53-90.76$ & \\
\hline
\end{tabular}

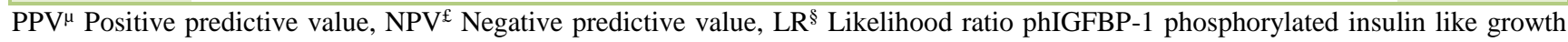
factor binding protein, FFN- fetal fibronectin

\section{Asymptomatic group}

In this group none of the patients delivered within 14 days of performing test. Only one patient out of 50 had positive FFN test and she delivered after 14 days. As none of the patients delivered within 48 hours, 7 days and 14 days, statistics was not computed. Ten patients delivered pre term (before 37 weeks) and all of them (100\%) were negative for both tests. Forty patients delivered after 37 weeks and only one $(2.5 \%)$ had positive FFN and five $(12.5 \%)$ had positive phIGFBP-1test. In this group only one patient had cervical length $\leq 25 \mathrm{~mm}$ and that patient delivered after 37 weeks. None of the patients that delivered pre term(10/50) had cervical length $\leq 25 \mathrm{~mm}$ sensitivity, Specificity , PPV, NPV of cervical length in predicting preterm delivery in asymptomatic group was $0 \%, 97.5 \%, 0 \%$ and $79.6 \%$ respectively. A comparison was made between predictive accuracy of two tests in both symptomatic and asymptomatic group (Table 2 and Table 3). In symptomatic group, two tests were found to have same NPVs in predicting delivery within 48 hours, 7 days and 14 days and that was $100 \%$, however FFN had higher PPV compared to phIGFBP-1 in predicting pre term delivery (Table 2). Similarly FFN also had higher NPV $(79.2 \%)$ compared to that of phIGFBP-1 (70\%). In asymptomatic group FFN had higher NPV as compared to phIGFBP-1. Risk estimation for pre-term delivery was done for both groups and it was seen that in asymptomatic group cervical length $>25 \mathrm{~mm}$ could rule out the risk of preterm delivery (NPV 79.6\%).

Table 3: Comparison of PhIGFBP-1 and FFN in predicting pre term delivery ( $\leq 37$ weeks) in asymptomatic group.

\begin{tabular}{|llllll|}
\hline & Sensitivity & Specificity & PPV & NPV & LR $^{\S}$ \\
\hline phIGFBP-1 & $0 \%(0 / 10)$ & $87.5 \%(35 / 40)$ & $0 \%(0 / 5)$ & $77.8 \%(35 / 45)$ & 2 \\
\hline $95 \%$ CI & $0-27.52$ & $73.89-94.5$ & $0-43.45$ & $63.78-87.46$ & \\
\hline FFN & $0 \%(0 / 10)$ & $97.5 \%(39 / 40)$ & $0 \%(0 / 1)$ & $79.6 \%(39 / 49)$ & \multirow{2}{*}{0.45} \\
\hline $95 \%$ CI & $0-27.75$ & $87.12-99.56$ & $0-79.35$ & $66.36-88.52$ & \\
\hline
\end{tabular}

$\mathrm{PPV}^{\mu}$ Positive predictive value, $\mathrm{NPV}^{£}$ Negative predictive value, $\mathrm{LR}^{\S}$ Likelihood ratio

phIGFBP-1: phosphorylated insulin like growth factor binding protein-1, FFN: fetal fibronectin

However, FFN could significantly predict the risk of preterm delivery in symptomatic (odds ratio 4.33 ; $95 \% \mathrm{CI}$ 1.23-15.20) and asymptomatic group (odds ratio1.30; 955 CI: 1.09-1.53). Similarly, phIGFBP-1 could significantly predict the risk of pre-term delivery in both symptomatic (odds ratio 4.03; 95\% CI: 1.20-13.52) and asymptomatic (odds ratio1.28; 95\% CI: 1.1-1.5) group. 
To find measure of agreement between phIGFBP-1 and FFN test in symptomatic group, kappa analysis was done. The value was 0.758 with $p=0.000$. This means $76 \%$ of the time the two tests are in agreement with each other and is statistically significant. In asymptomatic group, also the value of kappa analysis was 0.31 and this was statistically significant $(\mathrm{p}=0.002)$.

Table 4: Comparison of cervical length, ph IGFBP-1, FFN in predicting pre-term delivery ( $\leq 37$ weeks) in symptomatic group.

\begin{tabular}{|llll|}
\hline & $\begin{array}{l}\text { Cervical } \\
\text { length (CL) }\end{array}$ & $\begin{array}{l}\text { CL+ph } \\
\text { IGFBP-1 }\end{array}$ & $\begin{array}{l}\text { CL+FFN } \\
76 \%\end{array}$ \\
\hline Sensitivity & $\begin{array}{l}20 \% \\
(5 / 25)\end{array}$ & $\begin{array}{l}70 \% \\
(19 / 25)\end{array}$ & $(20 / 25)$ \\
\hline $95 \%$ CI & $7.6-41.3$ & $54.5-89.8$ & $58.7-92.4$ \\
\hline Specificity & $96 \%(24 / 25)$ & $\begin{array}{l}52 \% \\
(13 / 25)\end{array}$ & $\begin{array}{l}52 \% \\
(13 / 25)\end{array}$ \\
\hline $95 \%$ CI & $29.9-98.9$ & $31.8-71.7$ & $31.8-71.7$ \\
\hline PPV & $\begin{array}{l}83.3 \% \\
(5 / 6)\end{array}$ & $\begin{array}{l}61.3 \% \\
(19 / 31)\end{array}$ & $\begin{array}{l}62.5 \% \\
(20 / 32)\end{array}$ \\
\hline $95 \%$ CI & $36.5-99.1$ & $42.3-77.6$ & $43.7-78.3$ \\
\hline NPV & $54.5 \%$ & $68.4 \%$ & $72.2 \%$ \\
$(13 / 19)$ & $(13 / 18)$ \\
\hline $95 \%$ CI & $5.5-38.2$ & $43.5-86.4$ & $46.4-89.3$ \\
\hline $\begin{array}{l}\text { Likelihood } \\
\text { ratio (+) }\end{array}$ & 3.3 & 4.2 & 5.70 \\
\hline
\end{tabular}

CL- cervical length, phIGFBP-1 phosphorylated insulin like growth factor binding protein-1, FFN- fetal fibronectin.

In symptomatic group, cervical length $<25 \mathrm{~mm}$ is very specific and PPV in predicting pre term delivery is high i.e $83.3 \%$. When cervical length findings were combined with other two tests viz. phIGFBP-1 and FFN, NPV increases and statistical findings were significant (Table 4). In asymptomatic high risk group none of the patients had both cervical length $\leq 25 \mathrm{~mm}$ and positive test (either phIGFBP1 and FFN) and therefore statistics was not computed.

\section{DISCUSSION}

Several studies have shown that FFN test has a high NPV but low PPV for prediction of pre-term delivery, which means that a negative FFN test indicate a low risk of delivery but a positive test should not be interpreted as an indicator for admission. ${ }^{2,7,10}$ FFN test was found to have moderate accuracy for predicting preterm birth in a recent systematic review. ${ }^{11}$ The pooled estimates of sensitivity and specificity for delivery $<37$ weeks were $60.8 \%$ and $82.3 \%$ in their report. Cervical phIGFBP-1 has high NPV to predict preterm labor and thus may be of value in reassurance, avoiding unnecessary medical interventions. ${ }^{6,9,12,13}$ Altinkaya et al observed sensitivity, specificity, PPV and NPV of rapid phIGFBP-1 test for preterm delivery in symptomatic patients as $70 \%, 87 \%$, $56 \%$ and $92.5 \%$, respectively and in asymptomatic patients as $40 \%, 82.3 \%, 14.3 \%$ and $94.9 \%$ respectively before 37 weeks. ${ }^{12}$ We found slightly lower NPV of phIGFBP-1 for predicting delivery $<37$ weeks for both the groups (Table 2).

We found that the in symptomatic group cervical length measurement when combined with either phIGFBP-1 or FFN had a higher NPV than cervical length alone to predict pre term birth (Table 4). Nor Azlin et al also found that to predict preterm labor between 24-36 weeks in symptomatic women combination of phIGFBP-1 and cervical length had a higher NPV, PPV and specificity as compared to phIGFBP-1 or cervical length alone. ${ }^{9} \mathrm{NPV}$ : 97.8\% Vs $97.7 \%$ Vs $97.1 \%$, PPV: $80 \%$ Vs $51.1 \%$ Vs 23.5\%, specificity: $97.8 \%$ Vs $\quad 93.5 \%$ Vs $\quad 71.1 \%$ respectively (NorAzlin et al.). ${ }^{9}$ Similarly Danti L et al also observed that women with positive phIGFBP-1 and cervical length $\leq 30 \mathrm{~mm}$ had a significantly high risk of delivery before 34 weeks (LR 2.32, 95\% CI 1.15-4.46). ${ }^{14}$ Therefore, sonographically measured cervical length of $>25 \mathrm{~mm}$ with a negative phIGFBP-1 test in a symptomatic patient indicates a low risk of preterm delivery and may therefore allow avoidance of unnecessary therapies. ${ }^{15} \mathrm{NPV}$ for predicting the risk of pre-term delivery was increased on combining FFN assessment to cervical length measurements in present study also (Table 3) similar to that of Audibert F et al. ${ }^{8}$

In asymptomatic high risk group both FFN and phIGFBP1 tests were found to have poor sensitivity and PPV; however NPV of the tests were high. Cervical length in this group also had poor accuracy to predict preterm birth. Similarly another study found that in low risk women cervical length or cervicovaginal IGFBP were not significantly associated with pre term birth. ${ }^{16}$

On comparing the two tests in symptomatic group i.e FFN test and phIGFBP-1 to predict the risk of delivery within 7 days or before 37 weeks, positive likelihood ratio was higher for FFN test than for phIGFBP-1 (within 7 days 30.56 Vs 23.05, less than 37 weeks 16.7 Vs 5.5) with similar confidence intervals These results were in contrast to the study by Ting et al, in which phIGFBP-1 had slightly higher value in predicting delivery than FFN within 48 hours (1.00 Vs 0.97), within 7 days (0.92 Vs 0.89) and within 14 days $(0.92 \mathrm{Vs} 0.89) .{ }^{5}$ Riboni et al found slightly higher predictive values for phIGFBP-1 test than FFN test in predicting pre-term delivery. ${ }^{4}$ They observed that phIGFBP-1 and FFN test had a high specificity and a high negative predictive value in predicting pre-term delivery within 7 days (specificity 83.7 Vs 80.2, NPV 97.7 Vs 97.6) before 34 weeks (specificity 85.7 Vs 82.5, NPV 97.1 Vs 96.4) and before 37 weeks (specificity 89.2 Vs 85.9 NPV 90.8 Vs 88) gestation. Another study by Audibert et al found FFN alone or in combination with cervical length had better predictive accuracy than phIGFBP-1 for delivery within 2 weeks. ${ }^{8}$

In present study in symptomatic group $76 \%$ of the time the two tests were in agreement with each other. This finding was similar to Ting et al where $75 \%$ of the time two tests were in agreement with each other. ${ }^{5}$ Advantage of using 
phIGFBP-1 in contrast to FFN, is that only minimal amounts of IGFBP-1 are present in urine and seminal plasma. ${ }^{17}$ Therefore, recent intercourse and urine does not limit the use of the phIGFBP-1 test; however coitus is known to affect FFN tets results. ${ }^{18}$ Study by Tripathi et al showed that phIGFBP-1 test displayed higher sensitivity and NPV than did the fFN test for delivery before 34 weeks and within 7 days of testing $(\mathrm{P}<0.05) .{ }^{19}$ However both tests are relatively safe, easy to perform and can be performed by clinicians or paramedics even in rural settings. Rapid bed side dip stick tests for detecting FFN and phIGFBP-1 in cervicovaginal secretions are useful clinical adjuncts in ruling out delivery within 14 days of test in symptomatic patients, thus avoiding unnecessary hospital stay and medical interventions. However, FFN has slightly higher NPV in predicting risk of pre-term delivery.

Funding: No funding sources

Conflict of interest: None declared

Ethical approval: Not required

\section{REFERENCES}

1. Goldenberg RL, Mercer BM, Meis PJ, Cooper RL, Das A, McNellis D. The preterm prediction study: fetal fibronectin testing and spontaneous preterm birth. NICHD Maternal Fetal Medicine Units Network. Obstet Gynecol. 1997;87:643-48.

2. Sunagawa S, Takagi K, Ono K, Miyachi K, Kikuchi A. Comparison of biochemical markers and cervical length for predicting preterm delivery. J Obstet Gynaecol Res. 2008;34(5):812-9.

3. Rahkonen L, Kalio LU, Nuutila M, Sainio S, Saisto T, Paavonenet J. Cervical length measurement and cervical phosphorylated insulin-like growth factor binding protein-1 testing in prediction of preterm birth in patients reporting uterine contractions. Acta Obstetricia et Gynecologica. 2009;88:901-8.

4. Riboni F, Vitulo A, Avanzo MD, Plebani M, Battagliarin G, Patemoster D. Biochemical markers predicting preterm delivery in symptomatic patients: phosphorylated insulin-like growth factor binding protein-1 and fetal fibronectin. Arch Gynecol Obstet. 2011;284:1325-29.

5. Ting H.S. Chin PS, Yeo GS, Kwek K. Comparison of bed side test kits for prediction of pre-term delivery: nphosphorylated Insulin like growth factor binding protein 1 test and fetal fibronectin test. Ann Acad med Singapore. 2007;36(6):399-402.

6. Kekki M, Kurki T, Karkkainen T, Hiilesmaa V, Paavonen J, Rutanen EM. Insulin-like growth factorbinding protein-1 in cervical secretion as a predictor of preterm delivery. Acta Obstet Gynecol Scand. 2001;80:546-51

7. Tekesin I, Marek S, Hellmeyer L, Reitz D, Schmidt S. Assessment of rapid fetal fibronectin in predicting pre term delivery. Obstet Gynecol. 2005;105(2):280-4.
8. Audibert F, Fortin S, Delvin E, Djemli A, Brunet S, Dube J, Fraser WD. Contingent Use of Fetal Fibronectin Testing and Cervical Length Measurement in Women With Preterm Labour. J Obstet Gynaecol Can. 2010;32(4):307-12.

9. Nor Azlin MI, Bang HK, An LJ, Mohamad SN, Mansor NA, Yee BS, et al. Role of phIGFBP-1 and ultrasound cervical length in predicting pre-term labour. J Obstet Gynaecol. 2010;30(5):456-60.

10. Vogel I, Thorsen P, Curry A, Sandager P, Uldbjerg N. Biomarkers for prediction of preterm delivery. Acta Obstet Gynecol Scand. 2005;84(6):516-25.

11. Deshpande SN, Van Asselt ADI, Tomini F, Armstrong $\mathrm{N}$, Allen A, Noake C, et al. Rapid fetal fibronectin testing to predict preterm birth in women with symptoms of premature labour: a systematic review and cost analysis. Health Technol Assess. 2013;17:40.

12. Altinkaya O, Gungor T, Ozat M, Danisman M, Mollamahmutoglu L. 2009.Cervical phosphorylated insulin-like growth factor bindingprotein-1 in prediction of preterm delivery. Arch Gynecol Obstet. 2009;279(3):279-83.

13. Tanir HM, Sener T, Yildiz Z. Cervical phosphorylated insulin like growth factor binding protein -1 for the prediction of pre-term delivery in symptomatic cases with intact membranes. J Obstet Gynaecol Res. 2009;35(1):66-72.

14. Danti L, Prefumo F, Lojacono A, Corini S, Testori A, Frusca T. The combination of short cervical length and $\mathrm{Ph}$ IGFBP-1 in the prediction of pre-term delivery in symptomatic women. J Matern Fetal Neona. 2011;24(10):1262-6.

15. Paternoster D, Riboni F, Vitulo A, Plebani M, Avanzo MD, Battagliarin, Surico N, Nicolini U. Phosphorylated insulin-like growth factor binding protein-1 in cervical secretions and sonographic cervical length in the prediction of spontaneous preterm delivery. Ultrasound Obstet Gynecol. 2009;34:437-40.

16. Tripathi R, Tyagi S, Singh N, Mala YM, Singh C, Bhalla $\mathrm{P}$, Ramji S. Can preterm labour be predicted in low risk pregnancies? Role of clinical, sonographic, and biochemical markers. J pregnan. 2014;22:7.

17. Akercan F, Kazandi M, Sendag F, Cirpan T, Mgoyi L, Terek MC, Sagol S. Value of cervical phosphorylated insulin like growth factor binding protein 1 in the prediction of pre-term labor. J Reprod Med. 2004;49(5):368-72.

18. Faron G, Buyl R, Foulon W. Does recent sexual intercourse during pregnancy affect the results of the fetal fibronectin rapid test? A comparative prospective study. J Perinat Med. 2015;43(4):403-8.

19. Tripathi R, Tyagi S, Mala YM, Singh N, Pandey NB, Yadav P. Comparison of rapid bedside tests for phosphorylated insulin-like growth factor-binding protein 1 and fetal fibronectin to predict preterm birth. Int J Gynaecol Obstet. 2016;135(1):47-50.

Cite this article as: Singhal S, Sarda N, Dhiman N, Dogra K. Double blinded study on comparison of phosphorylated insulin like growth factor binding protein 1 test and fetal fibronectin test for prediction of preterm delivery. Int $\mathbf{J}$ Reprod Contracept Obstet Gynecol 2017;6:1347-51. 